\title{
Author Correction to: A novel theory of Asian elephant high-frequency squeak production
}

\author{
Veronika C. Beeck ${ }^{1 *}$, Gunnar Heilmann ${ }^{2}$, Michael Kerscher ${ }^{2}$ and Angela S. Stoeger ${ }^{1 *}$ \\ Author Correction to: BMC Biol 19:121 (2021) \\ https://doi.org/10.1186/s12915-021-01026-z
}

Following publication of the original article [1], the authors noticed that an incorrect file for Additional file 4 was captured. The corrected version of Additional file 4 is attached to this Correction and Additional file 4 has been updated in the original article accordingly.

\section{Supplementary Information}

The online version contains supplementary material available at https://doi. org/10.1186/s12915-021-01173-3.

Additional file 4. Acoustic camera video of a biphonation call and a squeak (left: $f, 55$ years, right: $f, 66$ years).

\section{Author details}

${ }^{1}$ Department of Behavioural and Cognitive Biology, Mammal Communication Lab, University of Vienna, Vienna, Austria. 'ªfai tech GmbH, Berlin, Germany.

Published online: 04 November 2021

\section{Reference}

1. Beeck, et al. A novel theory of Asian elephant high-frequency squeak production. BMC Biol. 2021;19:121. https://doi.org/10.1186/s12915-021-0102 $6-z$

The original article can be found online at https://doi.org/10.1186/s12915021-01026-z

* Correspondence: veronika.beeck@univie.ac.at;

angela.stoegerhorwath@univie.ac.at

${ }^{1}$ Department of Behavioural and Cognitive Biology, Mammal Communication Lab, University of Vienna, Vienna, Austria

Full list of author information is available at the end of the article
Ready to submit your research? Choose BMC and benefit from:

- fast, convenient online submission

- thorough peer review by experienced researchers in your field

- rapid publication on acceptance

- support for research data, including large and complex data types

- gold Open Access which fosters wider collaboration and increased citations

- maximum visibility for your research: over $100 \mathrm{M}$ website views per year

At $\mathrm{BMC}$, research is always in progress.

Learn more biomedcentral.com/submissions

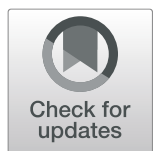

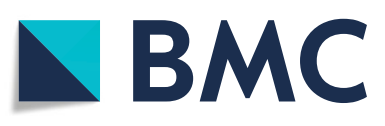

(c) The Author(s). 2021 Open Access This article is licensed under a Creative Commons Attribution 4.0 International License which permits use, sharing, adaptation, distribution and reproduction in any medium or format, as long as you give appropriate credit to the original author(s) and the source, provide a link to the Creative Commons licence, and indicate if changes were made. The images or other third party material in this article are included in the article's Creative Commons licence, unless indicated otherwise in a credit line to the material. If material is not included in the article's Creative Commons licence and your intended use is not permitted by statutory regulation or exceeds the permitted use, you will need to obtain permission directly from the copyright holder. To view a copy of this licence, visit http://creativecommons.org/licenses/by/4.0/. The Creative Commons Public Domain Dedication waiver (http://creativecommons.org/publicdomain/zero/1.0/) applies to the data made available in this article, unless otherwise stated in a credit line to the data. 